\title{
Whole-genome sequencing and disease-gene detection
}

\author{
Lynn B Jorde \\ From Beyond the Genome 2012 \\ Boston, MA, USA. 27-29 September 2012
}

Whole-genome sequencing (WGS) offers unique opportunities to identify rare variants that cause disease. We have developed a new software tool, VAAST (Variant Annotation, Analysis and Search Tool) that permits the identification of specific disease-causing mutations in WGS data. VAAST unambiguously identifies two disease-causing mutations in a family quartet in which both offspring have autosomal recessive primary ciliary dyskinesia and Miller syndrome. In addition, VAAST has identified a new X-linked progeria-like syndrome (Ogden syndrome) using exome data from two unrelated families. The mutation occurs in NAA10, which encodes an $\mathrm{N}$-acetyltransferase needed for $\mathrm{N}$-terminal acetylation of proteins. Functional studies demonstrate that the mutation causes a loss of function, and a genetic test has been developed for Ogden syndrome. We have also used VAAST to identify GATA4 as the cause of cardiac septal defects in a single four-generation pedigree. Using the Utah Population Database, we have identified a large multigenerational pedigree in which VAAST, combined with analysis of shared genome segments, identifies a new locus for Crohn disease. Finally, we present an application of VAAST in the identification of ATP1A3 as a causal gene for alternating hemiplegia of childhood.

Submit your next manuscript to BioMed Central and take full advantage of:

- Convenient online submission

- Thorough peer review

- No space constraints or color figure charges

- Immediate publication on acceptance

- Inclusion in PubMed, CAS, Scopus and Google Scholar

- Research which is freely available for redistribution

\section{Biomed Central}

